\title{
LANGUAGE ACCULTURATION: A CASE STUDY OF \\ MADURESE COMMUNITY IN MANDURO, JOMBANG, EAST
}

JAVA

\author{
Sofa, Yam Saroh \\ State University of Malang \\ sofataroki@gmail.com, yam.saroh@yahoo.com
}

\begin{abstract}
This article presents a case study of language acculturation particularly codeswitching which emerges in Madurese community in Manduro, Jombang, East Java. The purpose of this study is to portray the phenomenon of switching more than two languages and factors influencing it within the community to show the variety of Indonesian unique culture. To gain the data, interview was carried out and the recording script was elaborated. Based on the result, it was found that Madurese code-switch the languages of their mother tongue (Madurese), region based (Javanese) and national language (Bahasa Indonesia). The factors were marriage and trade.
\end{abstract}

Keywords: Language Acculturation, Code-Switching, Madurese Community, Manduro.

In approach to define what language is, Hammerl and Newby (2003) stated that, "Language is the medium to gather information and also communicate knowledge". Based on the definition, a theme line is noted that language is a device to share information and knowledge for communication purposes. In short, it can be said that language is an important bridge of communication.

Since language is used as bridge for information and knowledge sharing, language development is closed to the social environment because society is the user of the language. Amberg and Vause (2009) explain, "Language is foremost a 
means of communication, and communication almost always takes place within some sort of social context". They also add that to gain an effective communication needs an understanding and recognition toward language and its society. It shows that language is a communication device which quite related to society. Moreover, as people are social person, they need to connect and talk to others, and language is one of the devices which is applicable and useful to be used since it bridges people to understand what others mean.

Around the world, there are no certain and fixed rules how people in society naming, using and arranging the pattern of each language, it is so arbitrary. As Yule (2010) stated that the form of human language, particularly linguistic signs, may indicate any objects which have no relationship. Amberg and Vause (2009) explain, "An arbitrary sign does not possess any inherent connection with its meaning". It so uniquely depends on the community who uses the language. Due to fact that the form of linguistic signs can be gained through arbitrary system, it enables people to use two or more language as an arbitrariness in their daily conversation. They may use two or more languages in one moment of speaking.

In the process of using two or more languages, the language users gradually combine and adapt to the target language without forsaking their native language or mother tongue (McClintock, 2014). This process is then called as language acculturation. Bolaffi (2003) as cited in Keskin \& Blalock (2014), “Acculturation refers to the attainment of a new culture different from one's own." Furthermore Keskin \& Blalock (2014) explained, “acculturation includes both an individual's attainment of a new culture, as in the case of an immigrant adopting a new country's culture, as well as the attainment of another society's culture by a social 
group." It means acculturation may also happen in the form of language use as in the case of an immigrants who take their family living in a new place or state, then they decide to use their native language and the local language in which they live. In other word, it can be stated that acculturation in language enable people to learn or even use the target language in their daily life and blend it with their mother tongue or native language so they can merit and use both to succeed the communication.

Since it is possible for people to acculturate the use of language in their social environment, it gives a chance for people to be bilingual speaker. As Karahan (2005) states that knowing and being competence in two or more languages of an individual is called bilingualism. Furthermore, Wardhaugh (2006) explains, "In many parts of the word it is just normal requirement of daily living that people speak several languages: perhaps one or more at home, another in village, still another from purposes of trade and yet another for contact with the outside world of wider social or political organization". It means that those who are called bilingual are not only for those in which commonly speak using two or more languages but also for those who are even only understand the languages.

Other term which is commonly connected to bilingualism is diglossia. Different from bilingualism that focus on the individual, in diglossia, there is a "low" variety, acquired locally and used for everyday affairs, and a "high" or special variety, learned in school and used for important matters. (Yule, 2010). In Indonesian context, for example the students at home usually talk in their vernacular, the "low" variety, while at school they use Bahasa Indonesia as their "high" variety. While bilingualism focus on the individual who speaks two or 
more languages, this diglossia is focusing on the usage of the language they use in communication.

Regarding the factors of the bilingualism emergence in our society, Borbely (2005) mentions that factors of bilingualism are social, economic, and political change. In social change, movement of people and intermarriage become the core factors influence people to be bilingual speaker. Lightbown and Spada (2013) add that the acquisition and maintenance of more than one languages can open doors to many personal, social, and economic opportunities. Among the factors mentioned, movement becomes one of the strong factors which influence people to acquire other's language and make them to be bilingual speakers. In Indonesian context, Subyakto-Nababan (1992) propose two types of bilingualism in Indonesia, they are; bilingual who speaks regional language and Bahasa Indonesia and bilingual who speaks Bahasa Indonesia and foreign language.

A bilingual speaks either Bahasa Indonesia or another language because of some factors. The first factor is social interaction like trade, socialization, social and office matter. The second is the existence of local language. A local language has a position that is extremely different from Indonesian, so they use it in daily activity as their mother tongue. The third factor is the movement of people from one place to the other ones and the last is to make specific situation, and so on.

Based on the first type of bilingualism proposed by Subyakto-Nababan above, it can be concluded that most Indonesians are used to becoming bilingual speaker since they are accustomed to using both mother tongue (L1) and Bahasa Indonesia (L2) for their daily communication since they were children. In their early age (before going to school), Indonesian children are used to acquiring and 
using their mother tongue. Then in school - age - period (staring from 5 or 6 year - old), they start learning Bahasa Indonesia and use it for their communication at school.

In some cases, most of Indonesian students use both of the languages (L1 \& L2) in their communication either at school or at home (Subyakto-Nababan, 1992). The way they use the languages are commonly called code-mixing and code-switching. Muysken (2000) states, "Code-mixing refers to all cases where lexical items and grammatical features from two languages appear in one sentence". The definition above vividly explains that in code-mixing a speaker uses two or more languages in a sentence construction. This assumption suits to Indonesian reality in which most of the people are common to mix both their mother tongue as L1 and their second language (Bahasa Indonesia) as L2 in their sentence in one time of speaking.

Beside code-mixing, code-switching is another way of blending words from different languages in bilingualism aims to reach the communicative conversation between the speaker and listener. In some cases, code-switching is often admitted to be overlapping with code-mixing, moreover, some people say that both codemixing and code-switching are the same. However, there is a slight difference between them. Ayeomoni (2006) elaborates, "Code mixing is the embedding of various linguistic units such as affixes (bound morphemes), words (unbound morphemes), phrases and clauses from a co-operative activity where the participants, in order to infer what is intended, must reconcile what they hear with what they understand." Franceschini (1998) defines, "Code-switching is a language universal in the behavior of multilingual speakers". She elaborated that 
code-switching is one condition in which the user of a certain language using several languages or language varieties in the course of a conversation is based on conversation-internal mechanisms observable in various social contexts all over the world. Based on those definitions above it can be seen clearly the slight difference between code-mixing and code-switching, therefore, it can be said that both of those terms are interchangeable.

The previous study about code-switching was held by Shogren (2011). In this study, the researcher observed the patterns of language behavior of two fiveyear old bilingual children through the analysis of the code-switching and codemixing occurrences in their daily conversation. The objective of the study is to analyze the code and the motivation behind such pattern in order to see whether there are any differences between the two case studies. The result of the study shows that most common motivation behind the children's code choice is solidarity, referential, directive, and reactive to positive/negative face and power.

The second study was carried out by Sumarsih et al (2014). This study aims at studying the expressions exist for smoothing the communication, preventing misunderstandings and preventing deaths language speakers who use the code switching. The method is qualitative. Based on the study it is found that the 75 expressions of code switching exist in data that has been divided into word, phrase and sentence class. In addition, the subjects revealed that they use the code switching to look cool and to be up date in time. The third study was conducted by Kim (2006). The study aims at indicating the positive factors of code-mixing and code-switching for language education by discussing societal factors related to the reasons and motivations for these phenomena. He reviews a lot of sources 
to gain the data and the result of the study. Based on the study, there are some factors which affect code-switching and code-mixing such as grammatical, lexical, and societal factors. Among these factors, societal factors would be the most influential factors for the reasons why bilinguals switch and mix their languages. They are social situational factors like interlocutors, physical setting, other social variables like social status, race, age, etc.

Based on all previous studies, it can be concluded that most of the factors influencing the emergence of code-switching is societal factors. In Indonesian context, the existence of code-switching exist among the people's expressions in word, phrase and sentence class which means in Indonesia itself, the codeswitching has already in common used for society purpose to smooth the communication.

In Indonesian context, type of bilingualism commonly uses two languages (mother tongue and Bahasa Indonesia) in one moment of conversation. However Madurese in Jombang do not use two languages as bilingual speaker, they use three languages in one time of their speaking; Madurese, Javanese, and Bahasa Indonesia. It is unique since it is different from the normal situation which happens in Indonesia. Based on the data gained from the interview with the local people and Madurese in Manduro, it is known that Madurese in this village has lived in Jombang since years ago before the independence of Indonesia. At that time, Indonesia was colonialized by Netherland. Some Madurese ran away from their land, Madura Island, then arrived in Jombang and settled in a jungle in Jombang, East Java, which they thought that it was safe for their family. Since then, they started their lives by clearing the land to farm. 
The Madurese social and economic life is developed well day by day, so that they decided not to move back to their mother land, Madura Island. In line with their established economic lives, Madurese in this area started to learn Javenese and to use it in their daily conversation, particularly to speak with Javanese people for social and economic needs. Since then, the jungle in Jombang which has been changed by the Madurese as their home was called Manduro.

The uniqueness in this community is that even the Madurese have lived in Jombang as Java Island for years, they do not forget their mother tongue, they still actively use it in their daily activity. Even their descent who are not born in Madura Island, they are tought and practiced to speak Madurese. Therefore, it makes their descent are able to speak both Madurese and Javanese very well since they were child. This fact is also known by the researchers when they observed the daily conversation among Madurese in this village. To speak with people from the same village they use code-switching among Javanese, Madurese and Bahasa Indonesia. However, to speak with the researchers and other Javanese, Madurese from this village use only Javanese and Bahasa Indonesia. Knowing the fact, the researchers triggered to explore and describe the code switching happened in this community and also what factors which influence the language acculturation among the Madurese in Manduro.

\section{RESEARCH METHOD}

The design of this study was qualitative since in arranging this study the researchers explored the phenomenon of the language acculturation happened among Madurese in Manduro, Jombang, East Java since the language 
acculturation which happened in this village is uniquely different from other regions. People in this village are accustomed to code-switch three languages (Madurese, Javances, and Bahasa Indonesia) in their daily communication. Yin (2003) states that in qualitative, the researchers are allowed to explore individuals or organizations, simple through complex interventions, relationships, communities, or programs and supports the deconstruction and the subsequent reconstruction of various phenomena.

Due to the research design, the research data gained from observation, field note, and interview with Madurese and local people who live in Manduro. To gain the observation data, the researchers came to Manduro and observed how Madurese in this village interact each others. Based on the observation, the researcher used note taking to jot important information related to this study in the form of field note. Besides that, the researchers also recorded the conversation done by the Madurese in this village to be used as the supplementary documents to help the researchers in gather other information related to this study which may not include in the field note.

Then in the interview section, there were three people of Madurese and one local Javanese taken as the subjects of this study. They were two old men who knew very well about the history of Madurese in Manduro village and one adult man as the next generation of Madurese in this village. Then, one local Javanese who married with Madurese in this village and has been living in this village for years. After finishing the interview section with the all subjects, the researchers gathered all the data and select the research data based on the criteria related to aims of this study. Therefore, the researchers also did data reduction since not all 
the data gained were suited to be the research data. After that, the researchers started to analyze and elaborate the data to be the research findings.

\section{FINDINGS AND DISCUSSION}

Table 1 below shows some code-switching sentences found when interviewing the subjects. They were classified based on the languages switched.

Table 1. Language Switch Example between and among Languages

\begin{tabular}{|c|c|c|}
\hline & Sentence 1 & Sentence 2 \\
\hline Javanese and Bahasa & "Tapi nek yamenten nggeh & "Nek mriki, nggeh pun \\
\hline \multirow[t]{9}{*}{ Indonesia } & kan, nopo, libur nek sore" & biasa, sami kaleh tiang \\
\hline & & luar niku” \\
\hline & Tapi kalau sekarang- & Kalau kesini, ya sudah \\
\hline & sekarang ini kan, apa, libur & biasa, sama dengan \\
\hline & kalau sore (Bahasa & orang luar itu (Bahasa \\
\hline & Indonesia) & Indonesia) \\
\hline & $\begin{array}{l}\text { But at present time, it's, } \\
\text { free at evening (English) }\end{array}$ & $\begin{array}{l}\text { If in here, it's just } \\
\text { usual, same with }\end{array}$ \\
\hline & & people outside the \\
\hline & & community (English) \\
\hline \multirow{5}{*}{$\begin{array}{c}\text { Javanese and } \\
\text { Madurese }\end{array}$} & "karek...karek ngumpo" & "Jhe' tompak, tuntun" \\
\hline & & \\
\hline & Tinggal...tinggal & Jangan dinaikin, \\
\hline & memompa & dijalankan saja (Bahasa \\
\hline & Indonesia) & Indonesia) \\
\hline
\end{tabular}


You just need to add some Don't run it, just walk

wind into the tire (English) it (English)

\section{Javanese, Madurese See Appendix 2}

\section{and Bahasa Indonesia}

In sentence 1, the code switching between Javanese and Bahasa Indonesia, the speaker switched the Javanese word's 'prei' for Bahasa Indonesia noun's 'libur' and 'sonten' for sore. While in sentence 2, the speaker switched the Javanese word's njawi for Bahasa Indonesia noun's 'luar'. The conversation happened between Madurese and the researchers. As they knew that the researchers are not Madurese, so they speak both Javanese and Bahasa Indonesia. But in the other context of situation in other sentence in the example, they speak Madurese with their community. This is the first example of the code-switch and the existence of the language acculturation that they can speak not only their mother tongue (as seen in the other Madurese sentences), but also Javanese and Bahasa Indonesia. The similar example can be seen also in sentence 2 .

In sentence 1 Javanese and Madurese (detail of conversation can be seen in Appendix 1), code switching occured since it alternate sentences, although it was not two clauses in one sentence but between sentences. The Javanese sentence ‘karek...karek ngumpo’ existed among some Madurese sentences. In Sentence 2, as in Madurese, the sentences structure has a very similar form with what Javanese has. The word Jhe' in Madurese is ojok in Javanese and the complete sentence also has the same sentence structure. In Javanese the word 'tompak' does not exist but 'numpak' does, so the word 'tompak' is adapted by madurese from the word 'numpak' in Javanese. The word 'tompak' is the code-switching existed 
in this sentence. The word 'tuntun' is originally from Javanese means 'walk'. This sentences also supports the existence of code-switch and language acculturation in Madurese.

The code-switching among Javanese, Madurese and Bahasa Indonesia happened in the conversation in Appendix 2. The speakers were some Madureses and the researchers themselves. In the conversation, Madureses applied three languages. They used Madurese and Javanese when they spoke with the people within their community, and when they talked to the researchers they applied Javanese and Bahasa Indonesia. This means that they understand the situational context well, how they switch the language and apply the languages depends on their interlocutors shows that the language acculturation happens quite well.

Based on the examples and elaborations above, it could be seen explicitly that the code-switching exist there and they did it fluently, in one sentence they spoke Madurese, after that they switched to Javanese and when the researchers needed translation they shifted to Bahasa Indonesia. The language acculturation does exist since Madurese can speak three languages fluently and they understand the situational context perfectly. As they speak the new language, Javanese, they did not lose their mother tongue. They still speak their mother tongue, Madurese while speak Javanese and Bahasa Indonesia depends on the situation.

The condition was inline with Lightbown and Spada's statement (2013), "Highly proficient adult bilinguals code-switch when they speak to others who also know the languages they use". It was incredible to see how the Madurese community in Manduro succeed the process of cultural merit or in this case we could call it language acculturation which represented by the usage of their origin 
language or their mother tongue, Madurese and their current location language, Javanese. Not only that, but they also fluent in the usage of the National language, Bahasa Indonesia.

Regarding the factors influencing the process of code-switching, from the process of interview, observation and field note that the researchers took during the time spent with Madurese, some factors could be proposed as the reasons behind the succeed of the emergence and harmonization of Madurese and Javanese which lead to the language acculturation, there were two main factors; marriage and trade.

The first factor was marriage. As it has been explained, it is included as social factor since it happens for social interaction. The subject said that as their ancestors came in Jombang, interacting with Javanese and also marry people from Jombang or area nearby, they were very much influenced with the language of Jombang people, Javanese. And as they have some children, they applied both languages, Madurese and Javanese, so it was not a surprise that, their mother tongue had been mixed between those two active languages.

The second was dealing with trade demand. Trade can be categorized as social factor since it needs social interaction and also economy factor since it is dealing with value and/or money. As new people who came from another area, they need local people nearby to do the trading. And as most of them are farmers, they need to sell their crops to the city, and there, they cannot use their mother tongue language, therefore, Javanese and Bahasa Indonesia became the solution to bridge the communication so the trading come into succeed. 
In conclusion, it can be said that factors influencing the language acculuration are marriage (social) and trade (social and economic) factors.

\section{CONCLUSIONS AND SUGGESTIONS}

The uniqueness from Madurese who live in Manduro, Jombang, East Java was that they were still be able to keep and communicate actively in their mother tongue, although it has been years they live in Jombang, a territory that uses other language, in this case is Javanese as their daily language communication. This community was also fluent in using Javanese in their daily communication. Therefore, they mastered not only their mother tongue language but also Javanese and Bahasa Indonesia as the national language. This means that the language acculturation among Madurese in Manduro, Jombang, East Java was quite well. The factors influencing the code-switching there were marriage (social) and trade (social and economy).

As this research did not go deeper in revealing the pattern and motivation in bilingualism or multilingualism context, future research regarding code-switching and language acculuration using three languages may study about it. For wider context, a study about code-mixing, comparison of frequency between codeswitching and code mixing may be employed too in language acculturation.

\section{REFERENCES}

Amberg, J. S., \& Vause, D. J. (2009). American History: History, Structure, and Usage. Cambridge: Cambridge University Press.

Ayeomoni. (2006). Code-Switching and Code-Mixing: Style of Language Use in Childhood in Yoruba Speech Community. Nordic Journal of African Studies, 90-99. 
Broberly, A. (2005). Changes in Bilingual Language Choice Influenced by Real and Apparent Time: Panel Study in the Process of Languages Shift in a Romanian Minority Community Living in Hungary. 4th International Symposium on Bilingualism (pp. 328-340). Somerville: Cascadilla Press.

Hammerl, M. H., \& Newby, D. (2003). Second Language Acqisition: The Interface between Theory and Practice. Austria: University of Graz.

Karahan, F. (2005). Bilingualism in Turkey. 4th International Symposium on Bilingualism (pp. 1152-1166). Somerville: Cascadilla Press.

Kent, M. (2014). Acculturation Process and its Implications for Foreign Language Learners and Teachers. International Journal of Innovative Interdisciplinary Research, 1-10.

Kim, E. (2006). Reasons and Motivations for Code Mixing and Code Switching. English as Foreign Language, 43-61.

Lightbown, P. M., \& Spada, N. (2013). How Languages are Learned. United Kingdom: Oxford University Press.

Musyken, P. (2000). A Typology of Code-Mixing. Cambridge: Cambridge University Press.

Shogren, J. B. (2011). Analysis of Code-Mixing and Code Switching among Bilingual Children. Kansas: Wichita State University.

Sumarsih, Siregar, M., Bahri, S., \& Sanjaya, D. (2014). Code Switching and Code Mixing in Indonesia: Study in Sociolinguistics. English Language and Literature Studies, 77-92.

Yin, R. K. (2003). Case Study Research: Design and Method, Third Edition. CA: Sage.

Yule, G. (2010). The Study of Language. New York: Cambridge University Press. 


\section{APPENDIX 1}

Javanese and Madurese

The complete script is as follows:

ade' remmah cong?

ada lodde (a little bit unclear for the voice was very low)

iya, dang kebeh

karek...karek ngumpo

marehe bherri' ban anyar

apur a biddin (a little bit unclear for the voice was very low)

jhe' tumpak, tuntun

The rough translation is as follows:

Pinjam sepeda, tapi belum dipompa

Untuk transportasi ke sekolah

Tidak boleh dipakai berdua

Karena belum dipompa

(Bahasa Indonesia)

borrow a bicycle, but not yet pumped

as a transportation to school

but it cannot be used by two persons

because it is not yet pumped

(English) 


\section{APPENDIX 2}

Javanese, Madurese and Bahasa Indonesia’s Conversation.
A : ade' remmah cong?
B : ada lodde (a little bit unclear for the voice was very low)

A : iya, dang kebeh

A : karek...karek ngumpo

A : marehe bherri' bana nyar

A : apur a biddin (a little bit unclear for the voice was very low)

A : jhe' tompak, tuntun

R1 : ngomong apa mas tadi mas

R1 : nyuwun artine mas?

R2 : intinya minjem sepeda kayaknya
A : iya, benar
A : minjem, minjem sepeda
C : pinjam sepeda
C : tapi belum dipompa
A : kanggo tumpakan sekolah
R2 : oh, tumpakan sekolah, untuksekolah
C : nggak usah ditumpang berdua soalnya belum dipompa

In Bahasa Indonesia, the complete translation is as follows:
A : ada tidak remnya nak?
B : ada lodde (a little bit unclear for the voice was very low)
A : iya, dang bawa 
A : tinggal...tinggal memompa

A : sudah dibelikan ban baru

A : apur a biddin (a little bit unclear for the voice was very low)

A : Jangan dinaikin, dijalankan saja sepedannya

R1 : Ngomong apa mas tadi mas?

R1 : Bolehkan kami minta diartikan mas?

R2 : Intinya mau meminjam sepeda sepertinya

A : Iya, benar

A : Pinjam, pinjam sepeda

C : Pinjam sepeda

C : Tapi belum dipompa

A : Untuk transportasi ke sekolah

R2 : Oh, untuk digunakan ke sekolah, untuk belajar

C : Tidak perlu dipakai berdua, karena belum dipompa

In English, the complete translation is as follows:

A : does it have brake in it?

B : ada lodde (a little bit unclear for the voice was very low)

A : yes, you may bring it

A : you just need to pump it

A : someone had bought it a new tire

A : apur a biddin (a little bit unclear for the voice was very low)

A : Don't run it, just walk it

R1 : What did the conversation about? 
R1 : Do you mind to translate it for us?

R2 : It seems that the point is borrow a bicycle
A : Yes, correct
A : Borrow, borrow a bicycle
C : Borrow a bicycle
C : But it is not yet pumped

A : It is used for transportation to school

R2 : Oh, for riding to school, to study

C : But it cannot be used by two persons, because it is not yet pumped 